\title{
Gender in Political Sex Scandals in Contemporary Turkey: Women's Agency and the Public Sphere
}

\section{Dilek Cindoglu \& Didem Unal}

To cite this article: Dilek Cindoglu \& Didem Unal (2015) Gender in Political Sex Scandals in Contemporary Turkey: Women's Agency and the Public Sphere, Journal of Women, Politics \& Policy, 36:4, 464-485, DOI: 10.1080/1554477X.2015.1050911

To link to this article: http://dx.doi.org/10.1080/1554477X.2015.1050911

曲 Published online: 18 Nov 2015.

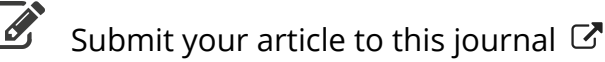

III Article views: 183

Q View related articles ¿

View Crossmark data $₫$

4 Citing articles: 1 View citing articles 


\title{
Gender in Political Sex Scandals in Contemporary Turkey: Women's Agency and the Public Sphere
}

\author{
DILEK CINDOGLU \\ Abdullah Gul University, Kayseri, Turkey \\ DIDEM UNAL \\ Bilkent University, Ankara, Turkey
}

\begin{abstract}
Sex scandals in politics lead to intense public debates about fundamental issues, such as morality, publicity, and privacy, rendering gender inequalities more visible than ever. This article aims to reveal the complex gendered dynamics of the political culture by looking at sex scandals in contemporary Turkey. The ways in which these scandals have been narrated, negotiated, and resolved among the public and political actors provide grounds for analysis about the nature of patriarchal dynamics regarding women's agency and public credibility communicated through their sexuality in contemporary Turkey.
\end{abstract}

KEYWORDS agency, public sphere, sex scandals, sexuality, Turkey

\section{INTRODUCTION}

The public sphere in Turkey, despite its rhetoric of equal access to all, rests on multiple exclusions including gender (Fraser 1990, 1992). Women's sexuality and autonomy are cast as an oxymoron in this exclusionary sphere. Women can participate in the public sphere as professionals and politicians, but they are still expected to remain submissive when it comes to the issue of autonomy and veil their sexuality.

Address correspondence to Dilek Cindoglu, AGÜ, Abdullah Gul University, Faculty of Social Sciences and Humanities, Sumer Campus, Kayseri, Turkey 38100. E-mail: dilekcindoglu@artuklu.edu.tr 
Extraordinary moments in political life, in which sex scandals suddenly erupt, lead to intense public debates about fundamental issues such as morality, publicity, and privacy. These moments render the structures of gender inequality more visible than ever because they reveal whose narrations are counted in the formation of public opinion. The Baykal/Baytok political sex scandal in 2010 could be considered such an exemplary moment in contemporary political life in Turkey because of its massive impact on the social and political debates that lasted over an extensive period of time following the scandal. This article aims to reveal the complex gendered dynamics of the political culture and the politics of public credibility in contemporary Turkey by analyzing this scandal of the former Republican People's Party (RPP) leader Deniz Baykal that resulted in his resignation from the party leadership in May 2010. The ways in which this scandal has been (1) narrated, (2) negotiated, and (3) resolved among the public and political actors provide us with clues about the nature of the patriarchal dynamics regarding women's agency, sexuality, and political participation in contemporary Turkey. Therefore, the article disentangles the gender asymmetries concerning privacy and publicity in the political realm, which have been revealed with the emergence of this political sex scandal that exposed the intricacies of the patriarchal political culture in Turkey.

A brief summary of the scandal is as follows: On midnight of May 7, 2010, a nine-minute video clip that purportedly depicted the former Republican People's Party (RPP) leader Mr. Deniz Baykal engaging in intimate moments with another RPP parliamentarian, Ms. Nesrin Baytok, in a bedroom, appeared on the Internet news sites. This incident led to a period of intense public debate and political turmoil among different political actors in Turkey. The Justice and Development Party (JDP) leader, Prime Minister Recep Tayyip Erdoğan, who represents conservative and moderate Islamic right wing politics (Heper and Toktaş 2003) and who has been in power since 2002, initially tried to ignore and censor the clip. However, because of modern Web technology, the clip immediately became accessible to the public through various Web sites, including YouTube, and the ban did not work as intended. ${ }^{1}$ In short, the Baykal/Baytok scandal, similar to the Clinton/Lewinsky scandal, unfolded in an era of new media politics that presented unforeseen challenges to Mr. Baykal's political leadership. ${ }^{2}$ As a result, probably for the first time in Turkish politics, due to the capacity for widespread and unfettered dissemination of content with new media technology, a sex scandal could not be avoided. ${ }^{3}$

The RPP members at first interpreted the event as a conspiratorial attempt by the JDP to make Mr. Baykal look bad in the media, forcing him to step down from the leadership and jeopardizing the credibility of the RPP in the public's eyes. However, when the spread of the video footage could not be controlled and public widely accessed the footage, it was no longer possible to rely solely on the rhetoric of conspiracy. Mr. Baykal's 
reputation was considerably damaged and his resignation became inevitable. Although in the beginning he was expected to run again for the leadership elections on May 22, 2010, he did not offer his candidacy. The only candidate who applied was Mr. Kemal Kılıçdaroğlu who succeeded unanimously and became the next president of the RPP after 18 years of Mr. Baykal's unchallenged power in the party.

By way of contrast, a similar political sex scandal broke out in Turkey just before the 2011 general elections, but these tapes were significantly different in nature than those in the Baykal/Baytok scandal and they were treated differently. They were also released on the Internet; however, the tapes showed male members of parliament (MPs) from the Nationalist Action Party (NAP) in casual intimate relationships with different women. Women's identities in those tapes were never revealed, and the public debate did not consider the identity of these women worth exploring. These tapes not only depicted the extramarital and intimate relationships of these politicians but also included demeaning and offensive conversations regarding their constituencies and displayed close sexual encounters in a group environment. The expulsion of these male politicians from further political staff participation within the NAP may be attributed to the fact that they had transgressed moral norms on several levels other than sexual misconduct.

However, in this article we are not dealing with the political sex scandals regarding the NAP because women's roles in those tapes were critically different. Public debates did not dwell on the women who were involved in this sex scandal at all, which is very likely due to the fact that the women did not possess political or professional identities. Therefore, in this article we argue that Ms. Baytok's situation is unique within the context of the recent political sex scandals in Turkey and requires further analysis. Unlike the women involved in the political sex scandal that erupted in the NAP, Ms. Baytok had been an influential political figure in the RPP inner circles and became an MP in 2007, which made her involvement in a scandal more controversial in the public debates.

The Baykal/Baytok sex scandal has been quite revealing in pointing out the gendered asymmetries characterizing the public sphere in Turkey. The public debates throughout the negotiation of the scandal were primarily loaded with discourses condemning the extramarital affair of the actors involved, investigating whether the videotape was a conspiracy, and emphasizing the protection of individuals' rights to privacy. ${ }^{4}$ Those who were critical of the use of the private lives of politicians for political gain only pointed out the illegality and immorality of recording and releasing such a videotape. Nevertheless, they missed the point that the whole evaluation of the event was extremely gendered. Ms. Baytok and Mr. Baykal were positioned unequally with respect to privacy and publicity. While Mr. Baykal did rightfully claim his privacy and contested the video images, Ms. Baytok, conversely, remained silent on the matter altogether. It is important to note that 
the involvement of Ms. Baytok, a married woman politician, in the scandal gave rise to a high degree of traumatic ripple effects on the public. Although having an extramarital affair is not acceptable for either gender, it leads to much more severe consequences for women in contemporary society in Turkey. Thus, Ms. Baytok, as a married woman politician, who "violated" the sexual norms of society by engaging in an alleged extramarital affair, became unqualified for politics in the public imagination, severely damaging her public credibility and causing her persona to be obliterated from the public.

Drawing on these public debates, this article attempts to unravel the gendered inequalities concerning publicity and privacy in Turkey. We will mainly investigate how patriarchal structures in the public sphere in Turkey give male actors in political life more power than women to draw the line between their public and private lives. To do this, we will focus on the ways in which this scandal has been (1) narrated, (2) negotiated, and (3) resolved among the public and political actors in different ideological positions.

\section{PUBLIC CREDIBILITY, GENDER, AND PUBLIC SPHERE}

The concept of "public credibility" could be useful to analyze the gendered character of the Baykal/Baytok political sex scandal. Public credibility connotes a realm of symbolic reference and defines the limits of what is publicly relevant, reasonable, and respectable ( $\mathrm{Ku} 2000,229)$. The symbolic public lays out the field of values, codes, representations, and discourses that actors can draw on to establish their public credibility ( $\mathrm{Ku} \mathrm{2000).} \mathrm{Accordingly,}$ actors shape their conduct in line with the moral and discursive boundary of publicity. In this article we argue that the workings of the concept of public credibility are extremely gendered. We investigate what happens to the public credibility of a woman politician when she surpasses the moral norms of society by displaying an autonomous sexual identity. Situating her position vis-à-vis the male politician, we study the public discourses applying to the public credibility of both parties. Our main focus here is on the working mechanism of the symbolic realm of values, codes, and discourses regarding public credibility and how it differs depending on the gender of the politicians. Dominant values and codes that have been historically predefined by both the state and society shape the processes of building and maintaining of public credibility, which in return result in a number of exclusions in the public sphere. In other words, building and maintaining of public credibility is closely related to the exclusionary nature of the public sphere. Gender is a main axis of exclusion; therefore, it permits us to observe the power asymmetries involved in the functioning of public credibility.

In the last decades feminist critique has posed significant challenges to the Habermasian theory of the public sphere. For Habermas (1989) the 
public sphere is a nonexclusive realm where private individuals gather to debate issues of common concern. In this understanding, the public sphere connotes an ideal of unrestricted rational discussion of public matters, which is open and accessible to all. Feminist scholars, alternatively, contend that Habermas' account idealizes the public sphere. They argue that despite the rhetoric of publicity and accessibility, the official public sphere rests on a number of significant exclusions, including gender (Cohen 1995; Fraser 1990, 1992; Landes 1988). Assuming that the public sphere is the space where emancipation and democratic liberties are realized, Habermas' account does not take into account the ways in which the public sphere can produce power relations that work against the equal participation of actors. The Habermasian account of the disinterested, rational debate in the public sphere, which is based on openness and inclusivity, turns out to be idealistic especially when it comes to the issues regarding moral values and discourses over the same by the public. Far from being disinterested subjects, actors in the public sphere, in general, are inclined toward improving their public credibility by remaining within the moral and discursive boundary of public life (Ku 2000). Yet if they fail to conform to the moral and discursive boundary of publicity, their access to the tools to restore their shattered credibility differs, depending on their gender. Thus, one may argue that the politics of public credibility is ignored by the Habermasian conception due to the argument about inclusivity and openness and the stress on disinterested, rational dialogue. Relying on the feminist critique of the Habermasian conception of the public sphere, this article reflects on the politics of public credibility during the negotiation of a political sex scandal in public discourse in Turkey.

In Turkey the crystallization of the gendered character of the public sphere could be observed most clearly in the hegemonic codes, discourses, and values of the public defined through gender identities. In this sense, women's visibility plays a decisive role in the definition of the boundaries of the public sphere in modern Turkey. Since the foundation of the Republic in 1923, the public sphere in Turkey has not been imagined as "a coming-together of critical-rational individuals that form organizations and then confront, resist and challenge the state, but rather as a domain whose contours are drawn and redrawn by the state" (Cindoğlu and Zencirci 2008, 794). Deeds, speech acts, and physical appearances of subjects in public have been highly controlled through construction of gender identities (Çınar 2005, 2008; Kadığlu 1994; Kandiyoti 1997). In this regard, there are mainly two dominant political projects regarding gender identities in Turkey: Kemalist and Islamist worldviews. ${ }^{5}$ Göle (1997) elaborates on this divergence by suggesting that two particular moments in Turkish history were especially important to detect the interlocking of gender, politics, and public sphere, and these were the secularist project of modernization in the 1920s and the movements of Islamization in the 1980s. The Kemalist modernization 
project regarded women's presence in the public sphere as the marker of the nation's belonging to Western civilization. Thus, women's visibility was encouraged through celebrating women's modern appearance and public roles (Çinar 2005). In a similar way, the Islamist movement in Turkey, which became quite strong in the post-1980s, attributed a symbolic meaning to the presence of the veiled women in the public sphere, which in turn made the "headscarf dispute" in Turkey more visible by protesting against the ban prohibiting their entrance into public schools with headscarves (Arat 2005). Relying on these two historical moments, Göle (1997) puts forward that regardless of the ideological positions of the political actors, women's corporeality in the public sphere appears as a discursive field in modern Turkey, in which the boundaries of the public sphere are negotiated.

Women's corporeal visibility and the attempts to regulate and use it are at stake in the struggle over the definition of the public sphere, at the same time the pervasive control over women's sexuality constitutes a pivotal pillar of the gendered discourse on the public sphere in Turkey (Kadıoglu 1991). Both modern and Islamist images of women are blended with values of modesty; the former is said to be "modern but modest," whereas the latter is built on the motto "Muslim thus modest" (Najmabadi 1991). From here, it is clear that no matter how divergent the political ideologies are, for the chief political actors in modern Turkey women's presence in the public sphere operates along with meticulous surveillance of women's sexualities.

\section{NARRATION OF THE STORY}

\section{Mr. Baykal's Version of the Story}

After the story of the scandal broke, Mr. Baykal (born in 1938) did not openly deny his possible sexual involvement with Nesrin Baytok or with any other women in his postscandal political speeches. Rather, his speeches were geared toward arguing that this was a plot made up by the government party to discredit him as the RPP leader. Moreover, he consistently avoided taking the matter personally and interpreted it as a general attack on the RPP. He also stressed that his resignation should never be regarded as an act of surrender; rather, in his view it was a sign of obvious resistance to the conspirators. His speeches displayed self-confidence and did not carry any expressions that could be interpreted as victim-like in any sense. The speech that he made on May 10, 2010, in a press conference two days after the outbreak of the scandal to announce his resignation from the RPP leadership clearly reflects this self-confident tone and thus is worth quoting at length:

I am announcing my opinion and my decision that has been expected for days. This is not simply a video clip, it is a plot. Such frame ups are illegal and corrupt acts. When you conspire against someone, sometimes 
you violate the principle of privacy. With hidden camera shots you cut and paste people's most vulnerable pictures, assemble and distort them. In this way you violate the sense of morals that is common to all religions and all people around the world. They do not care about human dignity and honor. Those who made up this plot did not do it because they are perverts or with the aim to blackmail. They did it to achieve some political goals.

This plot is manufactured. It is still very new, two weeks old. This plot does not aim at one particular individual. Its target is RPP's struggle to fight against the civil dictatorship in the country . . . It is not possible to arrange such a plot without getting the support of the ruling party ... The goodwill expressed in the aftermath of the conspiracy is not enough to obscure the guilt of the framers of the plot. Those who condemn are themselves the ones to be condemned.

I have something to deliver to those who say "what a shame!" You cannot defend immoral and illegal conspiracies by believing in them. Those who say "what a shame" make such conspiracies possible . . I will not surrender vis-à-vis this situation. If this requires paying a price and this price is to resign from the RPP presidency, I will pay for it. My resignation does not mean that I am running away. On the contrary, it means confrontation. With this understanding I am resigning from the RPP leadership: the target here is not me, but the RPP. ("Deniz Baykal İstifa Etti" [Deniz Baykal Resigned] 2010)

As an attempt to restore his credibility in the eyes of the public and his constituency, Mr. Baykal's lawyer hired a private investigation agency on the May 11, 2010, one day after his resignation. The report by that agency was released to the media on May 21, and it stated that the man in the videoclip was not Deniz Baykal and the woman was not Nesrin Baytok ("Ulusal Kriminal: Görüntülerdeki Baykal ve Baytok Değil” [National Criminal: Those in the Video Are not Baykal and Baytok] 2010). However, Mr. Baykal strictly refrained from making any declaration about his alleged affair with Ms. Baytok. Rather, his strategy was to guard the boundary of his privacy and to choose to deal with the scandal solely in terms of its public dimension (i.e., as an attack to the RPP). Thus, one might say that although his popularity in the public's mind was seriously shattered as a result of this sex scandal, Mr. Baykal did succeed in claiming his rights to privacy.

The support from the RPP ranks and also from the supporters of RPP for the continuation of Mr. Baykal's power proved crucial to cooling down the shocking effect of the scandal. RPP members convened in front of Mr. Baykal's house and shouted slogans asking Mr. Baykal not to leave the party ("CHP'den Baykal'a 'Geri Dön' Mitingi" [RPP Organized a 'Comeback' Demonstration For Baykal] 2010). Similarly, in the aftermath of the 
event, Mr. Baykal received many visits from RPP members (i.e., MPs, mayors, and provincial chairmen), who unanimously declared their support for him. Backed up by various political actors, in his public declarations Mr. Baykal was able to talk about his political career in a self-reliant manner and to state that he would keep on being active in politics as a parliamentarian, if not as a party leader. In contrast, however, there was no considerable public support of this sort for Ms. Baytok.

\section{Ms. Baytok's Version of the Story}

Nesrin Baytok (born in 1960), an engineer, had been working for the RPP since 1992 as an executive assistant for Deniz Baykal and had been nominated and elected in 2007 as an MP from the RPP. She was known as a powerful politician and the gatekeeper for the RPP presidency for the last 18 years. ${ }^{6}$ She is married to a businessman with a teenage daughter.

Nesrin Baytok's reaction to this scandal can be best described as complete silence. In the few interviews she volunteered after the scandal, similar to Mr. Baykal, she did not nullify the video footage either. She told the media that she was going through a difficult time, that her family was the only support that she enjoyed at the moment, and that she had no future plans for politics at the moment ("Nesrin Baytok İlk Kez Konuştu" [ Nesrin Baytok Spoke For The First Time] 2010). She was able to come to the parliament building three weeks after the scandal, accompanied by her husband ("Nesrin Baytok İlk Kez Mecliste" [Nesrin Baytok In the Parliament For the First Time] 2010). The bottom line is that throughout the aftermath of the scandal, she kept her silence about the video footage and the alleged intimate encounter with Mr. Baykal. However, one should note that Ms. Baytok's silence should be evaluated under quite different terms than Mr. Baykal's. Ms. Baytok's inability to confidently defend her position throughout the negotiation of the scandal in the public may be attributed to the patriarchal character of the public sphere, which does not tolerate the extramarital affairs of women in the same way that it does for men. By contrast, Mr. Baykal's silence (i.e., his refraining from directly talking about the alleged affair) was a tactical move displaying the agency of a powerful male actor to draw the line between his public and private selves. He strictly refused to talk about the alleged affair in the public realm. Ms. Baytok, conversely, could not defend her right to privacy in the public realm the way that Mr. Baykal did.

Not only did Ms. Baytok herself choose to remain silent about the event but the political actors who commented on the event in the media and the media coverage of the story itself also reduced her to silence. Newspapers from both ends of the political spectrum totally erased Ms. Baytok's name from coverage of the story.

Cumburiyet newspaper, for example, a well-known supporter of the RPP, announced the story with the following lines making no particular 
reference to the identity of Ms. Baytok, but rather referring to her as 'a woman': "Previous night in its website, Vakit newspaper published a video broadcast of a man, who is claimed to be Deniz Baykal, together with $a$ woman" ("CHP'ye Kaset Şoku" [Videotape Shock in RPP] 2010).

Hurriyet newspaper, known for its liberal political stance, reported the results of the investigation of the private detective by using a similar language and erased the identity of Nesrin Baytok, suggesting: "The man in the video is not Mr. Baykal and the woman is someone else" ("Görüntülerdeki Baykal Değil” [The Man in the Videotape Is Not Baykal] 2010).

Prime Minister Recep Tayyip Erdoğan also used a similar tone of eradication by referring to Nesrin Baytok as 'the other name': "Up until now, the main opposition leader has not said that he did not do such an act. The other name, who is involved, has not made such a declaration either" ("Başbakandan Eş Aldatma Açıklaması" [PM's Speech about Being Unfaitful to the Spouse] 2010).

However, Bülent Arınç, the deputy prime minister, overlooking Nesrin Baytok's identity, suggested that: "The lady who is alleged to be in the video clip is a politician, too and a parliamentarian indeed. They are both married ... I personally expect from Mr. Baykal and from the lady who is alleged to be there to state that there is no such thing" ("Böyle Bir Şey Yoktur Aç1klaması Beklerdim" [I Expected Baykal To Deny the Videotape] 2010).

These statements illustrate how the politicians who commented on the scandal and the reporters who narrated the event refrained from using Ms. Baytok's name, even though her persona was very well known to all, preferring to use labels such as "a woman," "the other name who is involved," or "the lady who is alleged to be there." These attitudes of the opponent and proponent media and the politicians can be interpreted as a denial of the woman politician's agency on the matters of sexuality. ${ }^{7}$

The almost unanimous consensus over refraining from openly mentioning Ms. Baytok's name can also be attributed to the paternalistic attitudes of the media and male politicians stemming from Turkish-Islamic modesty and prudery, which aim to minimize damage to the woman's honor in this case. This paternalistic attitude may have something to do with the fact that Ms. Baytok's involvement in the scandal was considered highly embarrassing and shocking to the public. Therefore, the attempts to refrain from mentioning her name in the coverage of the scandal could be regarded as damage control on behalf of Ms. Baytok, the political climate, and the general public. However, this attitude itself can be considered a sign of patriarchal control over woman's sexuality in Turkey, which disregards women's agency in the realm of sexuality.

It is true that the scandal resulted in severe consequences for Mr. Baykal. As mentioned, during the three weeks following the scandal, Mr. Baykal 
lost position in the RPP, which had never been contested in the previous 18 years. However, what is important here is that Mr. Baykal used all possible means to defend his position and privacy, including giving press conferences, interviews, and hiring a private detective agency. ${ }^{8}$ Moreover, although he quit the leadership of the Republican People's Party after the release of the videotape, one year later, in the general elections held on June 12, 2011, he ran for parliament and was reelected as a MP. What this signifies is that despite the fact that his reputation had been seriously damaged because of the scandal, there has not been any attempt to disqualify him from politics altogether, and he could carry on being active in the political arena.

Unlike Mr. Baykal, Ms. Baytok did not speak in front of the public after the scandal. As mentioned, in the only public statement that she provided to media she stated the following: "I am going through hard times; the only support that I get is from my family" (Nesrin Baytok İlk Kez Konuştu" [Nesrin Baytok Spoke for the First Time] 2010). Speculation about Ms. Baytok's personal motivation to remain silent is difficult. However, in this article, by using a feminist discursive analysis, we argue that Ms. Baytok's silence cannot be understood thoroughly without taking into account the fact that women's sexuality and autonomy are always cast as an oxymoron in the social and political context of Turkey. Considering the overarching patriarchal control on women's sexuality in Turkey, it can easily be suggested that the vulnerability of Ms. Baytok's position in the public sphere did not permit her to stand confidently in the public and defend her reputation and her rights to privacy.

Furthermore, one should note that the process of negotiation of the scandal resulted in Ms. Baytok's total disqualification from the field of politics. In the aftermath of the scandal, rumors had arisen that she lacked the credentials and experience to be an MP. Although she is a graduate of Middle East Technical University of Ankara, one of the most reputable universities in Turkey, and had gained political experience by serving for the RPP over 18 years, Ms. Baytok was accused of using her relationship with Mr. Baykal as an entrée into the parliament. ${ }^{9}$ In the end, she was not nominated as a candidate in the last general elections in June 2011. Considering the authoritarian party structures of Turkish politics (Ayan-Musil 2011), Ms. Baytok's case is not exceptional; most candidates are in fact nominated from the party leaders' lists, including but not limited to the RPP in contemporary Turkey. Therefore, it flies in the face of common practice and is patently unjust to disqualify Ms. Baytok from politics based on the mere fact that Mr. Baykal had nominated her. Indeed, Ms. Baytok had been involved in the political staff of the RPP for 18 years as an executive assistant and had probably gained more experience and vision in politics than many other candidates. 


\section{WOMAN AND PATRIARCHAL POLITICS: BAYTOK'S MARITAL STATUS AS A CRITICAL FEATURE IN THE SCANDAL}

Political life is highly gendered and full of gendered inequalities working against women (Lovenduski and Norris 1993). Unequal access to education and occupation, the burden of domestic responsibilities, and discriminatory rules of party politics obstruct women's participation in politics. Even when women succeed in entering the patriarchal arena of politics, quite often they have to deal with another set of gendered inequalities that are deeply embedded in the public imagination and in the routine workings of representational politics and therefore impede women's impact on policymaking. They may face "negative stereotyping" or be reduced to being judged solely on appearance (Huddy and Terkildsen 1993; Kahn 1996; Sreberny-Mohammadi and Ross 1996). Moreover, they are associated with the so-called feminine traits, emotionality and lack of leadership skills, and are therefore ghettoized to so-called women's issues, such as the family, education, and health care. Unlike their male counterparts, women's physical appearance and personal lives, rather than their professional skills and competencies, are so often fodder for public debates.

Throughout the negotiation of the Baykal/Baytok scandal the image of woman as politician experienced the most adverse treatment; her persona was subjected to total annihilation and obliteration from the public debates. The unraveling of the social and political discourses resulting in such a fatal consequence for a woman who had been active in politics for nearly 20 years gives clues about the nature of contemporary patriarchal politics in contemporary Turkey.

In Turkey, politics has always been an area that is reserved for men. Since the enfranchisement of women in 1934, women's representation in the parliament has always been very limited, symbolic, and extraordinary, and the highest echelons of politics have been closed to women's access (Tekeli 1981, 304). Women's presence in the political field historically has been mobilized by male support. Arat (1989) suggests that women MPs were predominantly encouraged by their fathers and husbands to participate. However, as Arat (1989) notes, once inside the halls of politics women politicians could no longer get male support and faced patriarchal power structures in doing politics. While engaged in politics, women may adopt male discourses with the aim of having their voices heard in conventional politics or political parties endorsing conservative gender discourses; therefore, women politicians' efforts to point out gender issues seems futile. Thus, it is argued that women's visibility in politics does not necessarily correspond to increased representation of women's needs and demands (Güneş-Ayata and Tütüncü 2008). Rather, it is quite likely that women in politics, as seen in the recent example of the Justice and Development Party, tend to tone 
down their public statements and adopt a much more modest stance with regard to political discussions related to women's issues (Güneş-Ayata and Tütüncü 2008).

These findings beg the question: how does a woman politician survive in the patriarchal political field in Turkey? It is more likely for a woman politician to gain an important place in the top decision-making bodies when she does not explicitly favor women's interests or display a commitment to feminist ideology. ${ }^{10}$ Moreover, the "ideal woman politician" in the Turkish context is expected to behave in a sexually modest manner-a more amplified version of the same modesty that is expected of women in public in general in Turkey that can best be summarized as not drawing attention to oneself in either one's dress or behavior. To climb the ladders of politics, she may feel obliged to display an ideal modest image to not cause any sexual implication (Güneş-Ayata 1995, 247). This patriarchal control over the woman politician not only restricts her actions in the political arena and limits her way of engaging in politics but also attempts to regulate her mores and manners in the realm of sexuality. The Baykal/Baytok scandal is very critical in this sense because it vividly crystallized how a woman politician in Turkey is exposed to patriarchal control over her behaviors regarding sexuality. This control is further reinforced by means of the emphasis on the familial roles of the women politicians. ${ }^{11}$ The "contract" between the woman politician and the patriarchal system stipulates that she cannot neglect her duties at home. This means that the career of the woman politician has to be built on her maintaining a traditional family life and therefore results in a tension between family and work. ${ }^{12}$ Failing to be an ideal mother and wife who is monogamous and faithful to her husband and family have resulted in severe consequences for a woman politician. In the Baykal/Baytok scandal, such a failure led to the termination of the woman politician's career.

\section{Ms. Baytok's Marital Status as a Critical Feature in the Scandal}

Scandals whose subjects are men crossing the boundaries of marital fidelity have been tolerated in Turkish political history to some extent especially when the woman in question is a single woman. ${ }^{13}$ As Göle (1997) argues, Islamic contexts treat women's modesty as a main discursive tool for controlling public visibilities and intimacies and the control of the public sphere heavily depends on the monitoring of women. Women's sexuality is exposed to constant surveillance under Islamic dictates and patriarchal values in Turkey. It is something that is explicitly addressed in Islamic custom and is justified because it aims to eliminate fitne, literally, chaos, and ensure public order. As a result, women's premarital and extramarital affairs may be considered beyond imagination in these contexts (Cindoglu et al. 2008, 245). Bearing this in mind, we suggest that it was not Mr. Baykal's involvement in the scandal per se; rather, it was Ms. Baytok's marital status that exceeded 
the Turkish public's acceptance level and led to severe consequences for both Mr. Baykal and Ms. Baytok.

In a similar way, in other Western political cultures, the situation is not that different when it comes to the toleration of men's extramarital affairs. When the male politicians are involved in extramarital affairs, the other women in the story are almost always single. The Clinton/Lewinsky affair could be a relevant example here. In 1998 US President Bill Clinton was accused of having sexual relations with the 22-year-old White House intern Monica Lewinsky. As the scandal erupted, Clinton felt no need to tender his resignation. In the aftermath of the scandal, the public surprisingly remained consistent in its support for Clinton (Sonner and Wilcox 1999).

However, neither secular Western nor Islamic conservative discourses regarding infidelity can conceive or tolerate an extramarital affair of a married woman. The possible polygamy of women is beyond the imagination and acceptance of public morality and is therefore punished severely (Cindoglu et al. 2008). Not only are married women's extramarital sexual relationships inconceivable in contemporary Turkey but even premarital sexual relationships of women are considered intolerable and exposed to harsh social censure. Reconstructive virginity surgeries are a reminder of just how pervasive and entrenched this norm is (Cindoglu 1997).

In that framework we can safely argue that the effects of the scandal for Ms. Baytok have been more dramatic due to her gender. It can be argued that what stretched the moral limits of the public was not necessarily the alleged polygamy of Mr. Baykal but rather Ms. Baytok's marital status. As a married woman, the alleged affair exposed her as being involved in an extramarital relationship and violated the dominant, patriarchal moral codes of sexuality in contemporary Turkey.

Conservative sexual codes regarding women's sexuality have been at the very center of the foundation of modern Turkey. To gain entry into the public sphere, formerly literally veiled Ottoman women could transition into modern Turkish women if they were willing to "veil" their sexuality in a male public domain. In this framework the new woman of the new Republic was "a well-educated, professional and socially active woman in the public sphere and a biologically functioning woman in the family fulfilling responsibilities as a wife and mother" (Durakbaşa 1998). One could claim that it is a similar patriarchal discourse that attempts to regulate Ms. Baytok's sexuality today and disqualifies her from the political arena. It is interesting to see that political parties, no matter how they diverge from each other on the political spectrum, can easily reach a consensus when it comes to patriarchal control over women's sexuality. Vis-à-vis the sex scandal in question, MPs from both from the RPP and the JDP could agree on the obliteration of the woman politician's career when she "failed" to submit to patriarchal control over her sexuality and justified the silencing of Ms. Baytok through their statements and attitudes. Neither side would pronounce her name while 
talking about the scandal nor did they react to her not being nominated as a candidate in the June 2011 elections. ${ }^{14}$

As stated above, the early Republican period created a new nation by regulating women's sexuality and the private sphere. Similar to this founding era, in the last three decades, during which Turkey witnessed economic and political liberalism, an elaborate conservative and patriarchal discourse on morality and family arose (Keçeli 2010). This has been a time when Turkey has gone through an all-encompassing transformation toward liberalization covering every aspect of life (i.e., economics, culture, politics, and art). In the midst of such a comprehensive transformation, the regulation of morality has made itself felt via various public discourses and regulations. In the realm of sexuality, for example, virginity, ${ }^{15}$ procreative sexuality, and monogamy for women have been strongly encouraged and homosexuality, premarital sex for women, and obscenities have been strictly denounced. Institutional interventions have been introduced for censorship. In 1994 RTÜK (Radio Television Supreme Council) was established along with the opening of many private TV channels and aimed to keep TV broadcasting under control in line with prevailing moral values. In addition to this new council, the Obscenity Law [Küçükleri Muzır Neşriyattan Koruma Kanunu] was amended to strictly censor obscene publications.

A further wave of strengthening of conservative moral values, patriarchal discourse, and orthodox norms of sexuality has come to the forefront with the JDP's coming to power in 2002. The conservative politics of the party places great emphasis on family and women's familial responsibilities. The family stands as the core value of conservative politics in the mindset of the JDP, and the disintegration of the family is perceived as the most threatening aspect of the modern era (Çitak and Tür 2008). The JDP even initiated a debate on the legal punishment of adultery in September 2004 with the aim of protecting the institution of the family in Turkey. Accordingly, the JDP leadership attempted to add a clause to the Turkish Penal Code that would make adultery a crime. ${ }^{16}$ Eventually, harsh criticism coming from the press, women's organizations, and the European Union (EU) prevented the JDP from adding the clause in question into the Penal Code. ${ }^{17}$ In addition to JDP's failed attempts to criminalize adultery, Prime Minister Erdoğan's call for couples to have at least three children could be regarded as another example that clearly reveals the party's conservative politics. ${ }^{18}$ This pronatalist approach attempts to regulate men's and women's reproductive capacities, regards a woman's womb as a discursive site to be utilized for political purposes, and defines the ideal woman citizen as someone who gives birth to at least three children. In brief, by heavily stressing the sanctity of the family in contemporary Turkey, defining familial responsibilities in a traditional way, and hampering women's autonomy in the realm of reproduction, the gender politics of the JDP makes women's public roles heavily dependent on their roles in the private realm. 
In this sense it is useful to read the Baykal/Baytok scandal and its gendered character against this background of strengthening conservative norms on sexuality and family in Turkey. This proliferating discourse may have increased the severity of the consequences of the Baykal/Baytok scandal for both actors, but it is certain that the actors were in no way treated evenly in the process of narration and resolution of the event.

\section{CONCLUSION}

The public sphere, despite its rhetoric of equal access to all, rests on multiple exclusions including gender (Fraser 1990, 1992). In this exclusionary sphere, from the point of gender, women's sexuality and autonomy are cast as an oxymoron. Even though women can participate in the public realm as professionals and politicians in contemporary Turkey, they are still expected to remain submissive when it comes to the issue of personal autonomy and to veil their sexuality.

Historically, women's sexuality has been a domain that has been highly controlled through various traditional, social, and political mechanisms in Turkey. The virginity examinations, reconstructive virginity surgeries, and honor killings can all be considered as some of the examples of this control. Patriarchal sexual moral codes cut across education and social status; both rural and uneducated women as well as highly educated and professional women even in high political ranks are silenced in the realm of sexuality. The Baykal/Baytok scandal is very emblematic in this sense because it evidently exposes how persistent and overarching the patriarchal norms and values are on women's sexuality in both discursive and praxis levels in contemporary Turkey.

The patterns of selection, emphasis, and interpretation of data that characterize the narration of the scandal in Ms. Baytok's position in the scandal can be subsumed under three categories: (1) Public opinion vilified Ms. Baytok's qualifications by arguing that she used her relationship with $\mathrm{Mr}$. Baykal to become an MP, whereas Mr. Baykal's misused authority in this process has never been questioned. (2) The scandal led to the view that Ms. Baytok no longer qualifies for the political arena. Ms. Baytok could not compete in the following general elections in 2011; the RPP leadership did not include her on the candidates list, whereas Mr. Baykal was reelected as an MP. (3) Except for a few timid feminist voices, public opinion totally ignored the gender dimension involved in the narration and resolution of the scandal.

It is certain that the scandal has led to severe consequences for both $\mathrm{Mr}$. Baykal and Ms. Baytok's political careers and public credibility, albeit with different levels of impact. Although he was not exempted from the sanctions of the conservative sexual regime, the effect of the scandal on her career was 
fatal. As the news about the scandal became more widespread, Mr. Baykal felt obliged to resign from the leadership of the RPP. However, throughout the negotiation process of the scandal, he acted in a self-confident manner and guarded his privacy by refraining from directly talking about the alleged affair, while Ms. Baytok remained silent.

The maintenance of public credibility, defined as a symbolic realm shaped by the actors in line with the moral and discursive boundaries of the public, becomes extremely difficult when actors fail to abide by the prevailing codes, values, and discourses of the community in which they live. Yet it is important to note that the negotiation of the public credibility of actors in the public debate is not exempt from the exclusionary character of the public sphere based on gender. Furthermore, whenever women's sexuality is acknowledged, discussed, or debated in the public sphere either in the context of an extramarital or premarital affair, this almost always works against the public credibility of the woman in question. In the Baykal/Baytok political sex scandal, the tools for restoring public credibility (i.e., giving press conferences, interviews, and reentering the parliament) are not evenly distributed among the actors. Fraser (1992) puts forward that the feminist analysis of a sex scandal in the public debate draws our attention to the gender-coded character of publicity and privacy. Through such an analysis, it becomes evident that only the male has the power to draw the line between the public and the private and to use the tools for restoring shattered public credibility.

Throughout this sex scandal, one witnessed female passivity, and in contrast observed the potent male actor with the power to speak and whose words carry greater weight when it comes to sexuality, personal morality, and autonomy. The reactions to this scandal, the narrations, and resolutions of it inform us about enduring patriarchal conservative values regarding women's sexual autonomy in the public. When analyzing the scandal from a feminist point of view, it is also important to take into account the marital status of Ms. Baytok. We claim that it was not Mr. Baykal's involvement in the scandal but rather Ms. Baytok's marital status that exceeded Turkish public's level of the acceptance and resulted in Mr. Baykal's fall from the power. The infidelity of a married man may be forgivable to an extent; however, his involvement with a married woman surpasses all moral codes of conducts and therefore exposed him to severe punishment by public censure in Turkey.

When the coverage and perception of the scandal is explored, it is revealed that the patriarchal and conservative moral vision that led to Ms. Baytok's name being removed from all references to the affair and that prevented her from speaking freely on her own behalf was prevalent in all the discourses of the political actors and the media across different ideological orientations. This consensus among the different political actors across political parties may provide an inspiring starting point for further research. This patriarchal character of the public sphere in Turkey, which is 
extremely pervasive, discourages women from employment in political staffs and constitutes one of the greatest hurdles hindering women's visibility and effectiveness in the political arena. It can prevent women from engaging in politics at all because the risks of "failure" to abide by the prevailing sexual norms of society carry such a heavy punishment. Whether real or imagined, evidence of sexuality that falls outside of the norms of conservative patriarchal values in Turkey remains an ever-present threat to a woman's career in politics, not to mention her personal life. Where public trust is a prerequisite to establishing one's position, the Turkish public is far more willing to forgive a male politician's sexual transgressions, especially when the "other" woman is anonymous and single and therefore possesses no social persona or status.

To conclude, the Baykal/Baytok scandal demonstrates that it is very hard for women in public positions to claim their privacy in the same way that men in public positions can. When men transgress the moral codes of the society, they might have been punished and demoted in their public roles and their public credibility may be severely shattered, but they can still keep the boundaries of the public and private lives. However, once women violate the codes of the sexual regime, it is almost impossible for them to draw the line between their public and private selves. We argue that this has a lot to do with the history of the constitution of public life in Turkey. In the Turkish context, women's corporeal visibility and attempts to regulate and use it are almost always at stake in the definition of the public sphere. Moreover, the pervasive control over women's sexuality constitutes a pivotal pillar of the gendered discourse on the public sphere in Turkey. As the Baykal/Baytok scandal revealed, for women to attain public roles and responsibilities in governance, and keep these roles, they have to surrender to the values of modesty. The display of sexually autonomous identities disqualifies women, in the eyes of the public, from playing a role in politics.

\section{ACKNOWLEDGMENTS}

We thank Fatima Sakarya and the editor and the anonymous reviewers of the Journal of Women, Politics and Policy for their valuable comments and assistance with this article.

\section{NOTES}

1. The Prime Minister Mr. Erdoğan's initial attempt to censor the broadcast of the videotape could be seen as a form of solidarity among men to cover up an extramarital affair. Though later he shifted toward more aggressive, judgmental, and moralist discourse against Mr. Baykal, he still did not even mention Ms. Baytok's name. This shift in positions requires further research. 
2. For an analysis about the challenges that the Clinton/Lewinsky scandal created for Bill Clinton's political leadership, see Owen (2000).

3. Can Dündar (2010) tells how RPP leader İsmet İnönü prevented the release of the love story of the prime minister Adnan Menderes and the opera singer Ayhan Aydan to the press in the 1950s. See Dündar (2010).

4. For discourses condemning a politician's involvement in an extramarital affair, see Murat Bardakç 2010. For an approach investigating whether the videotape is a conspiracy, see Fatih Altaylı 2010. For those who stress the protection of individuals' right to privacy, see Ertuğrul Özkök 2010 and Ahmet Hakan 2010.

5. We are aware of the fact that the discourses regarding the relationship between gender and public sphere in Turkey are not limited to the opposition between Kemalist-Secular and Islamist approaches. Especially the last two decades witnessed the multiplication of the gender discourses including more radical approaches criticizing both the secular-Kemalist and Islamist perspectives. Nevertheless, the critical feminist works do not make their way through mainstream political agendas as in the case of Cindoglu (2011). This article is interested in the hegemonic discourses that shape gender identities in the public sphere.

6. For an account of the powerful status of Ms. Baytok in the RPP, see "18 Yildir Mutfaktayd1, Şimdi Vitrine Çıktı" [She Was in the Kitchen for the last 18 Years, Now She is on the Stage]" 2007.

7. Because the public sphere is not an overarching space but rather encapsulates multiple competing publics (Fraser 1990), not all the discourses of the public debate about the Baykal/Baytok scandal were geared toward obliterating the persona of Ms. Baytok from the public realm. Some pointed out the gender dimension in the treatment of Mr. Baytok and Ms. Baytok in the public debate and stressed that women are always situated unevenly vis-a-vis men with respect to the matters of sexuality. The following newspaper articles are examples of this approach: Çalıslar 2010 and Berkan 2010. Also, one of the few names in the parliament who could see the gender dimension involved in the scandal was Güldal Akşit, a woman politician from JDP, working for the Parliamentary Commission of Opportunity of Equality for Women and Men. She declared that the real victim in the scandal is not the persona of Ms. Baytok or Mr. Baykal but the women in politics in general (Milliyet, May 25, 2010). Moreover, Çiğdem Aydın, the chairwoman of Ka-der, the Association for Supporting Women in Politics and Education said: "We are strongly against the media's treatment of the female deputy figure. Assuming a woman achieves such a high post by using her sexuality is neither just nor ethical. This wrong perception could 'kill' any future attempt by females to be involved in politics" (Dautaj-Şenerdem 2010).

8. As also mentioned at the beginning of the article, a similar case to the Baykal/Baytok scandal emerged in Turkey just before the 2011 general elections. Some videotapes were released on the Internet, showing male MPs from the Nationalist Action Party in intimate relations with two unidentified women. Eventually, the pressure on these MPs became so strong that they had to resign. This case also shows that the codes of the conservative sexual regime, which places the holiness of the family at the center, does not exempt men either from submitting to the family ideal. However, even though these male politicians are punished because of their "misconduct," their subjectivities are not totally obliterated and silenced in the public debate. The narrative of the scandal does not hide or shadow their names; they are treated as the subjects of the alleged event. Moreover, they could take action against the violation of their privacy by making a criminal complaint at the chief public persecutor's office and urging the court to put a ban on the broadcasting of the videotape.

9. See Sevilay Yükselir 2010.

10. The example of Tansu Ciller who served as the prime minister between 1993 and 1996 can be remembered in this respect. Arat (1998) argues that though Ciller has indirectly contributed to the women's cause by representing a role model for other women, she has been detached from women's problems and did not approach women as a distinct constituency.

11. How the discourse on the familial roles of women politicians works in the Turkish context has not been studied thoroughly so far and thus requires further attention.

12. Regarding this, by looking at gossip magazines in the Netherlands, van Zoonen (2000) points out that while the families of male politicians are described as sacrificing, families of female politicians are presented as suffering.

13. The aforementioned story about Adnan Menderes and Ayhan Aydan is one of the most wellknown examples.

14. Indeed, Mr. Erdoğan mentioned this issue during his elections campaign in Kastamonu. He accused the RPP of not being fair to Ms. Baytok: "What happened to that woman politician? They did 
not put her name on the candidate list. Why, is it because she was the only one who was guilty? Weren't they both guilty?" ("Erdoğan: Baykal aday, o hanım niye değil?" 2010). Although in this statement Erdoğan seems to point out the gender inequality in the coverage of the Baykal/Baytok scandal, he instrumentalizes the scandal and even the gender dimension here to appeal to the public and gain electoral supremacy. He himself refrains from treating Ms. Baytok as a full subject and does not pronounce her name.

15. In the 1990s there was a lot of media coverage of the stories about girls who have been forced to virginity examination or who committed suicide to escape this state-enforced examination. In 1997 Iş1lay Saygin, the then-minister in charge of women's affairs, in one of her public talks, defended virginity examinations as a vital means to guard the indigenous customs and traditions. For a detailed account, see Parla (2001).

16. As a reaction to the draft law criminalizing adultery, on September 14, 2004, hundreds of women marched to the Grand Assembly with the slogan, "our body and our sexuality is ours." However, the PM Recep Tayyip Erdoğan denounced this protest by saying that placards of the protesting women were not in line with the traditional values of the society and that these "marginal" women cannot represent the ideal Turkish woman (Zaman, September 25, 2004).

17. For further analysis of the adultery debate in Turkey, see Müftüler-Baç and Onar (2011).

18. On March 8, 2008, attending a gathering on the occasion of Women's Day, Erdoğan urged women to have at least three children and warned that failing to preserve a young population would endanger the future of the nation ("Turkish Prime Minister under Fire for Urging to Have More Children" 2008).

\section{REFERENCES}

"18 Yıldır Mutfaktaydı, Şimdi Vitrine Çıktı" [She Was in the Kitchen for the last 18 Years, Now She is on the Stage]. 2007. Milliyet. http://www.milliyet.com. tr/2007/07/09/pazar/axpaz02.html (April 18, 2012).

Altaylı, Fatih. 2010. "Kıldan Tüyden Savunma" [A Defence Based on Bodily Hair]. Habertürk. http://www.haberturk.com/polemik/haber/516748-medyada-kasetaciklamalarinin-yansimalari (April 18, 2012).

Arat, Yeşim. 1989. Patriarchal Paradox: Women Politicians in Turkey. Rutherford, NJ: Fairleigh Dickinson University Press.

Arat, Yeşim. 1998. "A Woman Prime Minister in Turkey: Did It Matter?" Women and Politics 4 (4): 1-22.

Arat, Yeşim. 2005. Rethinking Islam and Liberal Democracy: Islamist Women in Turkish Politics. New York, NY: SUNY Press.

Ayan-Musil, Pelin. 2011. Authoritarian Party Structures and Democratic Political Setting in Turkey. New York, NY: Palgrave MacMillan.

Bardakçı, Murat. 2010. "Bu İşe Zina Denir" [This Is Called Adultery]. Habertürk. http://www.haberturk.com/yazarlar/murat-bardakci/516714-adiniacikca-koyalim-bu-ise-zina-denir (April 18, 2012).

"Başbakandan Eş Aldatma Açıklaması" [PM's Speech about Being Unfaithful to the Spouse]. 2010. Hurriyet. http://webtv.hurriyet.com.tr/2/6444/0/1/basbakandan-es-aldatma-aciklamasi.aspx (July 15, 2010).

Berkan, İsmet. 2010. "Türkün Röntgencilik, Sex ve Ahlakla İmtihanı" [Turks' Ordeal with Sex, Voyeurism and Morality]. Radikal. http://www.radikal. com.tr/Radikal.aspx?aType $=$ RadikalYazar\&ArticleID $=996680 \&$ Yazar=ISMETBERKAN\&CategoryID=97. (April 18, 2012). 
"Böyle Bir Şey Yoktur Açıklaması Beklerdim" [I Expected Baykal To Deny the Videotape]. 2010. Cumburiyet. http://www.cumhuriyet.com.tr/?hn=138674 (July 15, 2010).

Çalışlar, Oral. 2010. "Nesrin Baytok'a Bir Özür Borcumuz Var” [We Owe an Apology to Nesrin Baytok]. Radikal. http://www.radikal.com.tr/Radikal.aspx?aType= RadikalYazar\&ArticleID $=996834 \&$ Yazar $=$ ORAL-CALISLAR\&CategoryID $=98$ (April 18, 2012).

Cindoğlu, Dilek. 1997. "Virginity Tests and Artificial Virginity in Modern Turkish Medicine.” Women's Studies International Forum 20 (2): 253-61.

Cindoğlu, Dilek. 2011. Headscarf Ban and Discrimination: Professional Headscarved Women in the Labor Market. Istanbul: TESEV Publications.

Cindoğlu, Dilek, and Gizem Zencirci. 2008. "The Headscarf in Turkey in the Public and State Spheres." Middle Eastern Studies 4 (5): 791-806.

Cindoğlu, Dilek, Murat Cemrek, Sule Toktas, and Gizem Zencirci. 2008. "The Family in Turkey: The Battleground of the Modern and the Traditional." In Families in a Global Context, eds. Charles. B. Hennon and Stephan M. Wilson. New York, London: Routledge Press, 235-63.

Cohen, Jean. 1995. "Critical Social Theory and Feminist Critiques: The Debate with Jürgen Habermas." In Feminists Read Habermas: Gendering the Subject of Discourse, ed. Johanna Meehan. New York, London: Routledge, 57-91.

Çınar, Alev. 2005. Modernity, Islam and Secularism in Turkey: Bodies, Places and Time. Minneapolis, MN: University of Minnesota Press.

Çınar, Alev. 2008. "Subversion and Subjugation in the Public Sphere: Secularism and the Islamic Headscarf." Signs 33 (4): 891-913.

Çitak, Zana, and Özlem Tür. 2008. "Women between Tradition and Change: The Justice and Development Party Experience in Turkey." Middle Eastern Studies 44 (3): 455-69.

"CHP'den Baykal'a 'Geri Dön' Mitingi” [RPP Organized a 'Come-back' Demonstration for Baykal]. 2010. Hurriyet. http://arama.hurriyet.com.tr/ arsivnews.aspx?id=14733698 (July 15, 2010).

"CHP'ye Kaset Şoku" [Videotape Shock in RPP]. 2010. Cumburiyet, May 8, 2a.

Dautaj-Şenerdem, Erisa. 2010. "Turkish Activists Condemn Shame Campaign against Woman in Video Scandal" Hurriyet Daily News, May 14.

"Deniz Baykal İstifa Etti" [Deniz Baykal Resigned]. 2010. Hurriyet. http://www. hurriyet.com.tr/gundem/14678573.asp (July 15, 2010).

Dündar, Can. 2010. "Milli Şef Rakibinin Aşk Skandalının Belgesi Getirilince NeYapmıştı? [How Did the National Chief React When the Love Scandal of His Competitor Came Out?] Milliyet, May 13.

Durakbaşa, Ayşe. 1998. "Kemalism as Identity Politics in Turkey." In Deconstructing Images of the Turkish Woman, ed. Zehra Arat. New York, NY: St. Martin's Press, 139-57.

"Erdoğan: Baykal aday, o hanım niye değil?" 2011. http://www.ntv.com.tr/arsiv/id/ 25209786/ (March 31, 2015).

Fraser, Nancy. 1990. "Rethinking the Public Sphere: A Contribution to the Critique of Actually Existing Democracy." Social Text 25 (26): 56-80.

Fraser, Nancy. 1992. "Sex, Lies, and the Public Sphere: Reflections on the Confirmation of Clarence Thomas." Critical Inquiry 18 (1): 595-612. 
"Görüntülerdeki Baykal Değil" [The Man in the Videotape Is Not Baykal]. 2010. Hurriyet, May 21, 28a.

Habermas, Jürgen. 1989. Structural Transformation of the Public Sphere: An Inquiry into a Category of Bourgeois Society. Cambridge, MA: MIT Press.

Hakan, Ahmet. 2010. "Alçağın Zaferi" [The Victory of the Dishonest]. Hürriyet. http:// www.hurriyet.com.tr/yazarlar/14667456.asp?yazarid=131\&gid=61 (April 18, 2012).

Heper, Metin, and Şule Toktaş. 2003. "Islam, Modernity and Democracy in Contemporary Turkey: The Case of Recep Tayyip Erdoğan." Muslim World 93 (2): $157-86$.

Huddy Leoni, and Nayda Terkildsen. 1993. "Gender Stereotype and Perception of Male and Female Candidates." American Journal of Political Science 37 (1): 119-47.

Göle, Nilüfer. 1997. "The Gendered Nature of the Public Sphere." Public Culture 10 (1): 61-81.

Güneş-Ayata, Ayşe. 1995. "Women's Participation in Politics in Turkey.” In Women in Modern Turkish Society, ed. Şirin Tekeli. London and New Jersey: Zed Books, $235-50$.

Güneş-Ayata, Ayşe, and Fatma Tütüncü. 2008. "Party Politics of the AKP (20022007) and the Predicaments of Women at the Intersection of the Westernist, Islamist and Feminist Discourses." British Journal of Middle Eastern Studies 35 (3): 363-84.

Kadıoğlu, Ayşe. 1991. "Alaturkalık ile İffetsizlik arasında Birey Olarak Kadın" [Woman as an Individual in between Being Alla Turca and Unchastity]. Görüş 9: 58-62.

Kadıoğlu, Ayşe. 1994. "Women's Subordination in Turkey: Is Islam Really the Villain." Middle East Journal 48 (4): 645-60.

Kahn, Kim Fridkin. 1996. The Political Consequences of Being a Woman: How Stereotypes Influence the Conduct and Consequences of Political Campaigns. New York, NY: Columbia University Press.

Kandiyoti, Deniz. 1997. "Gendering the Modern: On Missing Dimensions in the Study of Turkish Modernity." In Rethinking Modernity and National Identity in Turkey, eds. Reşat Kasaba and Sibel Bozdoğan. Seattle, WA: University of Washington Press.

Keçeli, Öncü. 2010. Constructing Morality for Turkey: The Moral Campaign of the 1980 s as a Novel Technique of Governing. Unpublished PhD thesis. Bilkent University.

$\mathrm{Ku}$, Agnes S. 2000. "Revisiting the Notion of Public in Habermas' Theory: Towards a Theory of Politics of Public Credibility." Sociological Theory 18 (2): 216-40.

Landes, Joan. 1988. Women and the Public Sphere in the Age of French Revolution. Ithaca, NY: Cornell University Press.

Lovenduski, Joni, and Pippa Norris. 1993. Gender and Party Politics. Thousand Oaks, CA: Sage.

Müftüler Baç, Meltem, and Nora Onar. 2011. "The Adultery and Headscarf Debates in Turkey: Fusing 'EU-niversal' and 'Alternative' Modernities." Women's Studies International Forum 34 (5): 378-89. 
Najmabadi, Afsaneh. 1991. "Hazards of Modernity and Morality: Women, State and Ideology in Contemporary Iran." In Women, Islam and State, ed. Deniz Kandiyoti. Philadelphia, PA: Temple University Press, 48-76.

"Nesrin Baytok İlk Kez Konuştu" [ Nesrin Baytok Spoke for the First Time]. 2010. Radikal. http://www.radikal.com.tr/Radikal.aspx?aType=RadikalDetayV3\& Date $=\&$ ArticleID=995997 (July 15, 2010).

"Nesrin Baytok İlk Kez Mecliste" [Nesrin Baytok in the Parliament for the First Time]. 2010. Hurriyet. http://www.hurriyet.com.tr/gundem/14857247.asp (July 15, 2010).

Owen, Diana. 2000. "Popular Politics and the Clinton/Lewinsky Affair: The Implications for Leadership." Political Psychology 21 (1): 161-77.

Özkök, Ertuğrul. 2010. "Mukaddes Yatak Odası" [The Holy Bedroom]. Hürriyet, May 12, 2010. http://hurarsiv.hurriyet.com.tr/goster/haber.aspx?id=14696949 \&yazarid=10 (April 18, 2012).

Parla, Ayşe. 2001. "The Honour of the State: Virginity Examinations in Turkey." Feminist Studies 27 (1): 65-88.

Sreberny-Mohammadi, Annabelle, and Karen Ross. 1996. "Woman MPs and the Media: Representing the Body Politic." Parliamentary Affairs 49 (1): 103-15.

Sonner, Molly W., and Clyde Wilcox. 1999. "Forgiving and Forgetting: Public Support for Bill Clinton during the Lewinsky Scandal." PS: Political Science and Politics 32 (3): 554-57.

Tekeli, Şirin. 1981. "Women in Turkish Politics" In Women in Turkish Society, ed. Nermin Abadan-Unat. Leiden: Brill, 293-311.

"Turkish Prime Minister Under Fire for Urging to Have More Children." 2008. http://www.hurriyet.com.tr/english/turkey/8448562.asp?gid $=231 \& 52=52955$ (March 31, 2015).

"Ulusal Kriminal: Görüntülerdeki Baykal ve Baytok Değil" [National Criminal: Those in the Video Are Not Baykal and Baytok]. Hurriyet. http://www.hurriyet.com. tr/gundem/14781626.asp (July 15, 2010).

Van Zoonen, Liesbet. 2000. "Broken Hearts, Broken Dreams? Politicians and Their Families in Popular Culture." In Gender, Politics and Communication, eds. Annabelle Sreberny and Liesbet van Zoonen. Cresskill, NJ: Hampton Press, 101-20.

Yükselir, Sevilay. 2010. "Hepimiz Nesrin Baytok'uz!" [We All Are Nesrin Baytok]. Sabah. http://www.sabah.com.tr/Yazarlar/yukselir/2010/05/14/hepimiz_ nesrin_baytokuz (October 1, 2012). 